\title{
Stepping towards sustainable urban drainage practices at Acari River Basin in Rio de Janeiro
}

\author{
M. G. Miguez ${ }^{1}$, L. P. C. de Magalhães ${ }^{2}$ \& F. F. deAraújo ${ }^{1}$ \\ ${ }^{I}$ Polytechnic School, Federal University of Rio de Janeiro, Brazil \\ ${ }^{2}$ COPPE, Federal University of Rio de Janeiro, Brazil
}

\begin{abstract}
Acari River basin, located at the north zone of Rio de Janeiro city, is one of the most populated regions of this city (with $20 \%$ of its total population) and encompasses an area of $107 \mathrm{~km}^{2}$. This watershed is characterized by medium and low-income occupations and suffers from various different problems due to its non-planned urbanisation. Flooding is one of the most critical and complex issues in this region of the city. This problem is worsened by factors such as intense urbanisation, high imperviousness rates, riverbanks and floodplain occupation, existence of hydraulic singularities, tidal influence, among others. In order to manage this situation, the Municipality proposed a canalisation project based on the enlargement of Acari River. This measure alone was not able to solve the problem as it could transfer the flood downstream to highly occupied low-lying areas. In order to adjust design concepts, Federal University of Rio de Janeiro conducted a research searching for a more sustainable flood control measures set. The study was carried out with the support of a hydrodynamic cell model. The model was calibrated based on an intense real flood event and applied to the simulation of scenarios representing present situation and combinations of several structural measures (including the canalisation project). The results have shown that a sustainable solution can be achieved through the combination of the proposed channel design project with other measures such as storage structures, multifunctional landscapes and communities relocation.
\end{abstract}

Keywords: urban floods, sustainable urban drainage, mathematical modelling. 


\section{Introduction}

Acari river basin covers a large portion of Rio de Janeiro City, about $107 \mathrm{~km} 2$, with several densely populated neighbourhoods. Acari river has one important tributary to its left bank, called Calogi River, and a set of major tributaries to its right bank: Cachorros, Pedras, Tingui, Afonsos, Caldereiro, Piraquara and Catarino rivers. Both Acari and Pavuna rivers join to form São João de Meriti River, which flows to Guanabara Bay. Figure 1 presents a map with the basin limits and its main rivers.

Land use at the basin is varied. There are residential areas, commercial areas, a military housing area, a military airport, important highways, electric transmission line towers and buffer zones and a few green areas.

Part of Acari river basin occupation is not considered as a formal city. Slums near riverbanks and on slope areas compose this irregular urban occupation. Poverty and lack of infrastructure plays a significant role on communities settled there. Sanitation is not adequate and river water quality suffers from this. Environment degradation is a natural consequence of the whole situation. The main river itself shows signs of solid waste disposal, garbage accumulation and erosion/sedimentation processes appearing in several reaches. Urban planning is loose or simply lacks.

The basin is also subjected to frequent heavy floods. There are records of more than $2 \mathrm{~m}$ of inundation depths in some critical areas. The Mayor's Office estimates that floods on Acari river basin affect about 20.000 people directly, and more than 150.000 people indirectly, because of urban infrastructure disruption during inundations. Tidal influence at river outflow also limits the basin discharge capacity. Land value at the basin is decreasing along time and some commercial areas are being abandoned because of flood hazards (Rio de Janeiro Mayor's Office [1]).

This set of problems pictures a critical situation and, in this context, the Municipality of Rio de Janeiro intends to develop a river basin revitalisation program. One of the first issues referred to urban floods. Mayor's Office proposed, as a first approach, a direct intervention on the main riverbed, in order to canalise natural downstream reaches, rectify sharp angle curves and replace low bridges restrictive to flow. Eventually, part of the population would have to be relocated from risk areas. Parks alongside the river were also proposed to recover degraded areas. Although these measures sound reasonable, there were some complementary questions not easy to answer and Municipality was not entirely convinced about the effectiveness of the canalisation project proposed.

Canalisation tends to transfer flood problems downstream and, in this case, it could be critical as densely occupied low-lying areas are located at the basin's lower reaches. In fact, flood problems are spread all over the basin, affecting not only the main river, but also its tributaries. Alone, the canalisation of the main river is not sufficient to minimise floods on Acari river tributaries. Moreover, it was also difficult to predict the combined effects of the proposed measures due to their spatial and temporal effects combination. 
Considering these factors, a complementary study was conducted at Federal University of Rio de Janeiro, aiming to review and complement the project design conception. A mathematical cell model was applied in order to represent the basin in an integrated way, allowing the assessment of the expected effects of the proposed flood control measures.

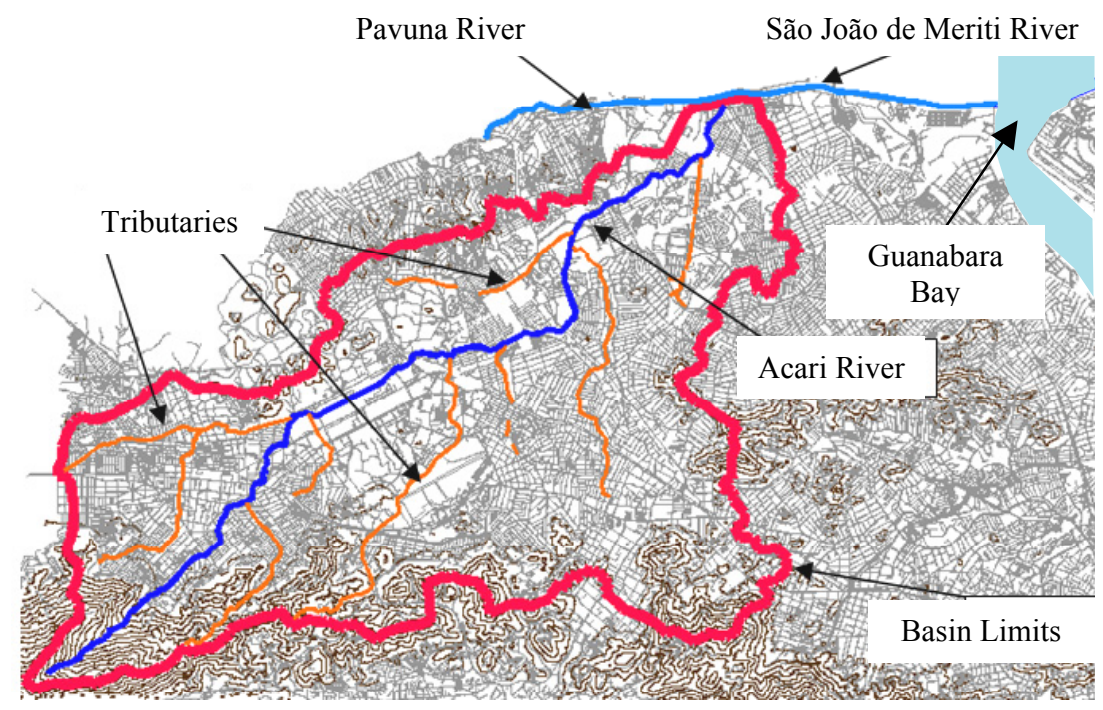

Figure 1: $\quad$ Map of Acari river basin.

\section{Urban floods and mathematical modelling}

An important question, when discussing urban flood modelling, is that the entire basin must be represented in a systemic way, in order to encompass the temporal and spatial variability of the phenomenon. This kind of comprehensive approach allows the simulation of integrated actions over the basin, joining traditional end of pipe interventions with distributed measures aiming to retain and infiltrate stormwater flows.

The interest in urban flood modelling is increasing, once urban floods appear as one of the most frequent, serious and costly problems that cities must face nowadays. Different models, with varied characteristics and objectives, were constructed to represent floods. In the present study, MODCEL (Mascarenhas et al. [2]), an academic model developed in Federal University of Rio de Janeiro, was chosen to simulate Acari river basin.

The development of MODCEL was based on the concept of flow cells (Zanobetti et al. [3]). MODCEL is an urban cell model, which integrates hydrologic processes, observed in each cell, with a hydrodynamic looped model, in a spatial representation that links surface flow, channel flow and underground pipe flows. This model is able to integrate the drainage net with the urban 
landscape, allowing the construction of a flow net that exceeds the formal drainage net limits. For instance, streets may act as channels, park walls may act as weirs, buildings, parks and squares may act as storage reservoirs. Different types of cells and links give versatility to the model. The cells, solely as units or taken in pre-arranged sets, are capable to represent the watershed scenery, composing more complex structures. The definition of a set of varied flow type links, which represent different hydraulic laws, allows the simulation of several flow patterns that can occur in urban areas. Therefore, the task related to the topographic and hydraulic modelling depends on a pre-defined set of cell types and possible links between cells.

The modelling of Acari river basin considered: the use of a hydrological model to represent upstream reaches, with no flooding problems, which were treated as boundary conditions; and the use of MODCEL to represent flood prone areas, including the main course of Acari river and its tributaries. Tidal influence was considered as another boundary condition. Figure 2 shows a schematic representation of the modelling strategy applied to Acari river Basin. Considering a 20-years time of recurrence design storm, model simulation showed a critical flood condition. There are extensive flooded areas due to overbank flows, as well as to local hydraulic singularities. Figure 3 shows the flood map obtained for the adopted design storm.

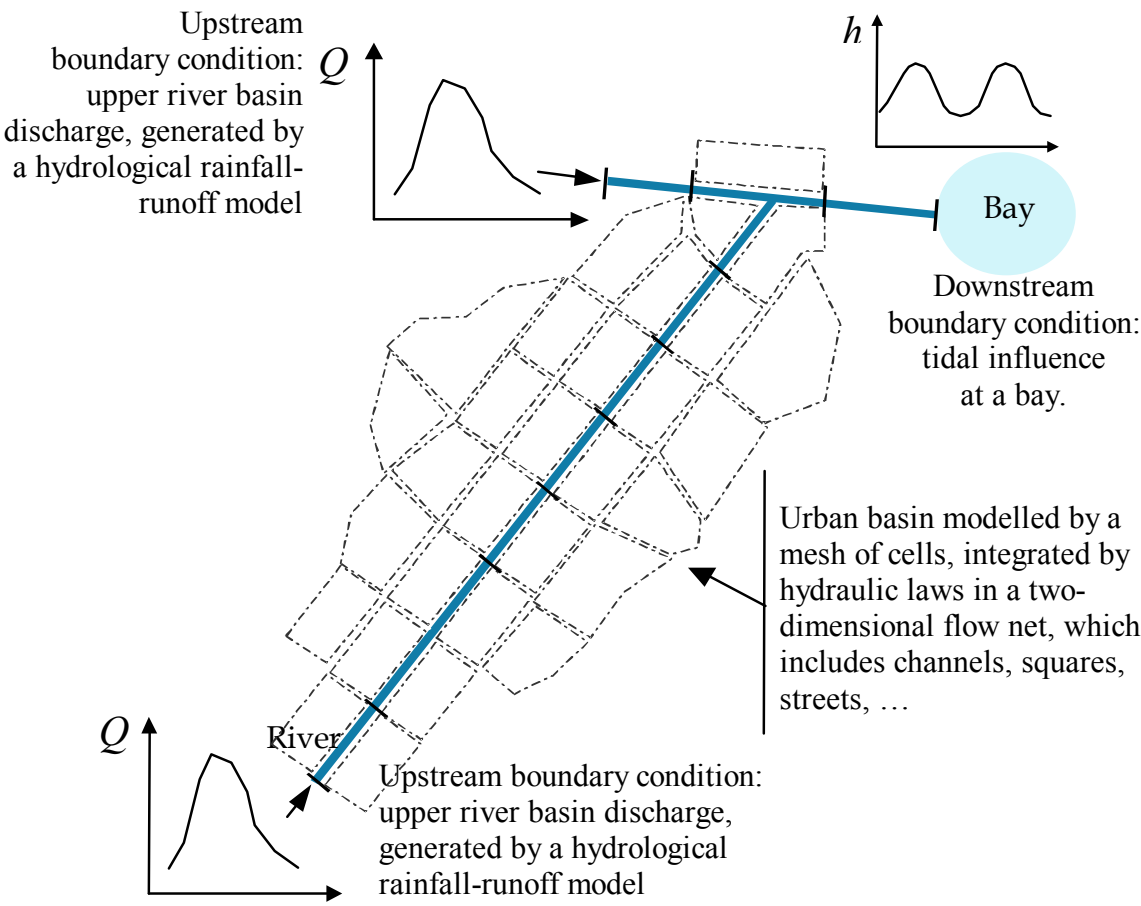

Figure 2: Schematic modelling of Acari basin. 


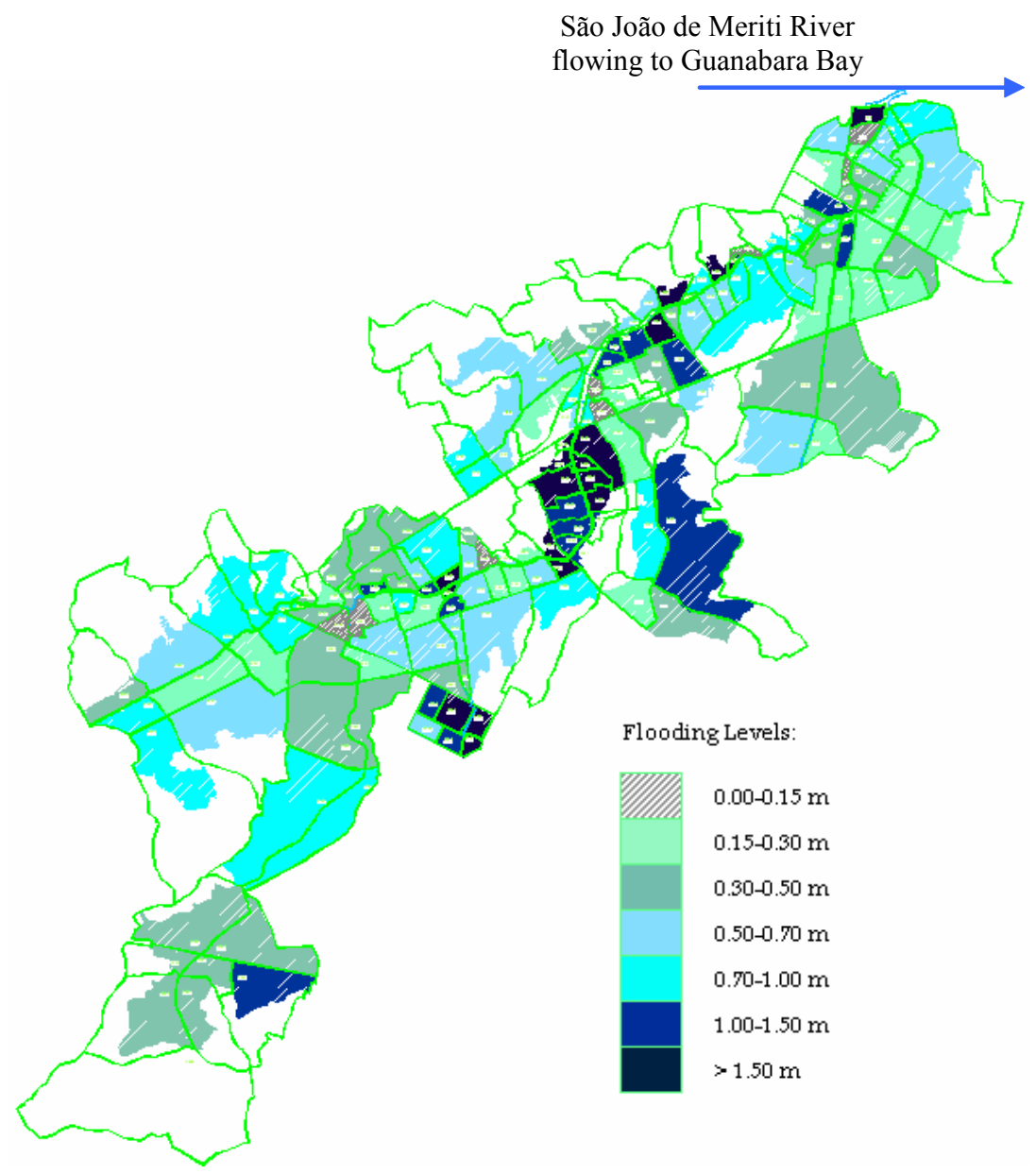

Figure 3: $\quad$ Flood map for present situation at Acari River basin.

\section{First approach: traditional canalisation works}

Two public offices of Rio de Janeiro Municipality proposed two different projects for Acari River Basin. Urbanism Office proposed a program aiming the renewal of Acari River Basin urban areas, focusing on sustainable urban development concepts. This program, called "Acari River Alive", considered different issues in order to achieve its purposes. The solutions for transportation problems in the basin were treated in order to allow a changing in the patterns of accessibility of the neighbourhoods and the solutions proposed were integrated with greenways, mainly used as linking space elements, as discussed by Ahern [4]. Parks were designed at riverbanks sites and part of the communities living in 
inappropriate conditions were supposed to be relocated; and a significant urban retrofit was intended. However, this project did not directly addressed actions to solve urban floods, although some of the proposed measures could be integrated with a flood control project (Seams [5]). On the other way, Urban Waters Office, aiming to minimise floods and complement "Acari River Alive" Program started to work with an existent project, which was not yet implemented. The main proposal of this previous project was related to an extensive canalisation of downstream reaches. Taking this project into account lead to what was considered the first approach to try to solve the problem, but this approach needed a review. Moreover, the possibility of transferring flood problem had to be properly addressed. Figure 4 presents details of a low reach of Acari river canalisation, showing clearly the traditional concept of maximising conveyance, with river rectification and enlargement.



Figure 4: Canalisation works, enlarging and rectifying a downstream Acari River reach.

\section{Alternative approach: sustainable drainage design}

Taking into account the situation discussed in the previous topic and considering the intentions of "Acari River Alive" program, flood problem needed to be faced and an alternative approach was then driven towards a sustainable proposal. In this context, urban flood mitigation was taken as an opportunity to change the urban patterns of the basin and retrofit the area. Neighbourhood renewal depends on flood zoning and urban flood control. By its side, urban flood control measures can assume multifunctional aspects and become to act in an integrated way with urban landscape features (Miguez et al. [6]). Besides, urban flood control measures, distributed over the basin, are able to recover pre-urbanisation flow patterns. This consideration approximates the flood control design project 
and the urban planning and development process. In this way, the revision of Acari canalisation project could be able to include some complementary measures, capable to recover flow patterns, diminish flow peaks and regain storage capacity for the basin, in a more sustainable approach. Reorganising flow patterns in space and time is not a simple task, but is the key to adjust flooding to acceptable levels that can be maintained as time passes by. Therefore, canalisation was revised and complementary measures were proposed. In fact, canalisation was maintained in localised reaches to correct singularities and punctual obstructions. Along the river, dredging was recommended to recover flow capacity of the channels, without needing to enlarge them. Besides, the complementary distributed measures proposed featured a set of different interventions containing: dumping reservoirs construction; detention ponds at parks; detention at riverbanks; relocation of communities in low-lying risk areas; and elimination of channel restrictions.

In order to detail and illustrate the flood control measures proposed, figure 5 shows the location of the main distributed interventions proposed and a set of 6 control points spread around the basin, where flood mitigation results are compared with present situation. In the sequence, from upstream to downstream, figures 6 to 10 show each particular proposed measure with their local effects. Global effects are presented in table 1, where flood levels are compared at the 6 control points, chosen to cover the spatial distribution of the modelled flood.

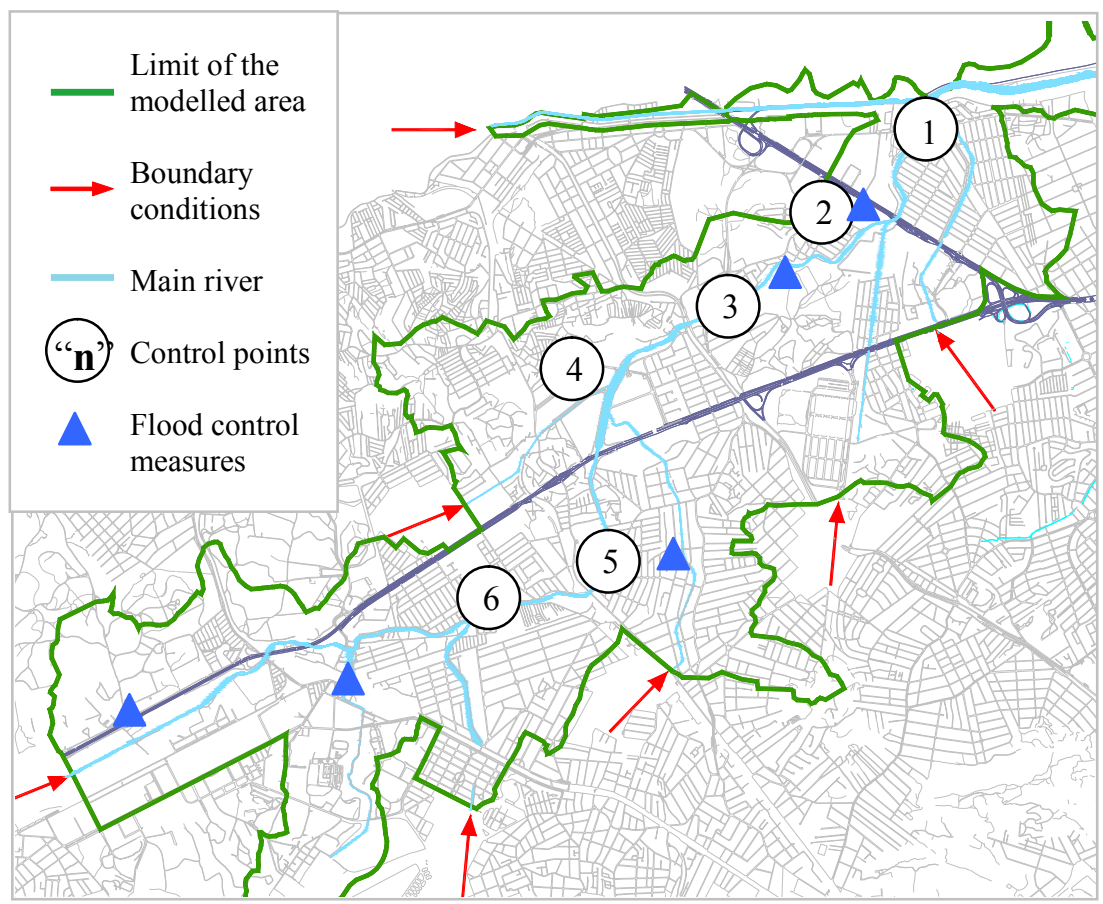

Figure 5: Control points and intervention sites: Acari River basin. 

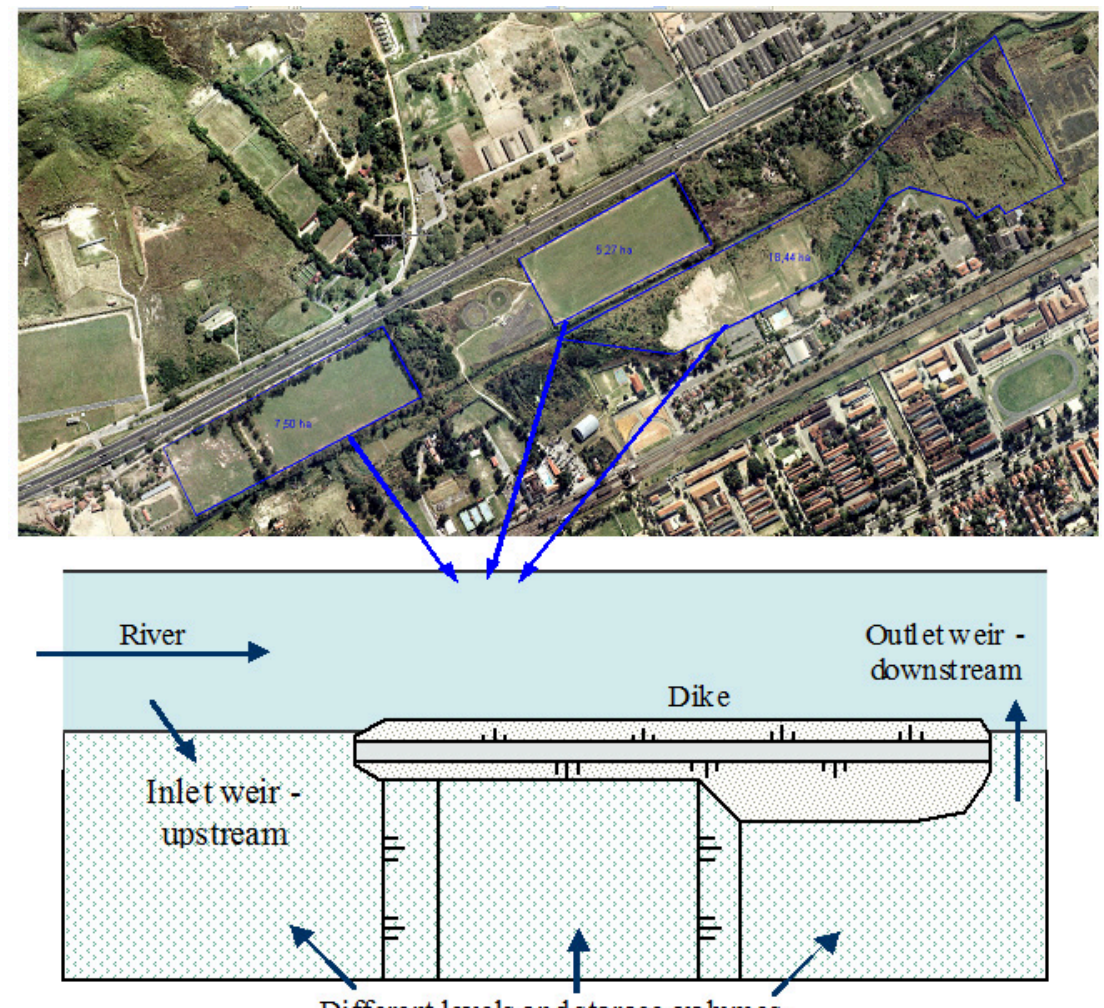

Different levels and storage volumes.

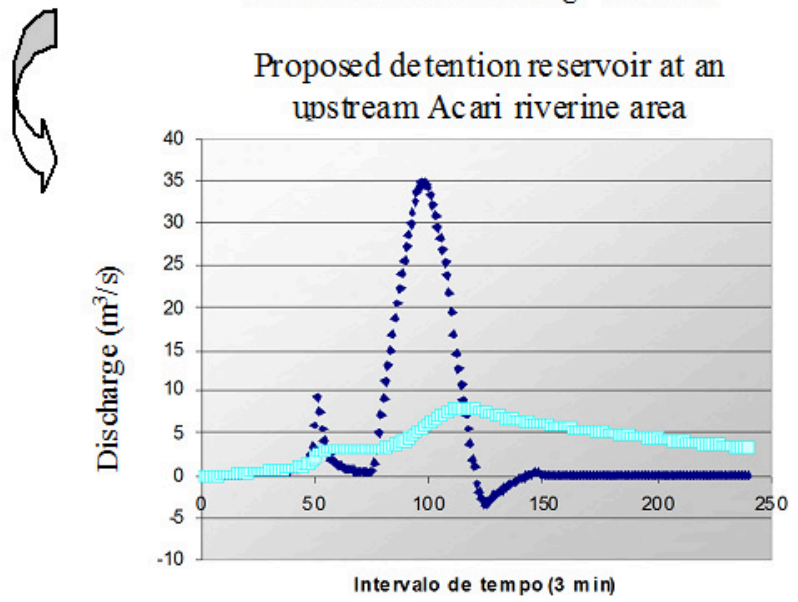

Time intervals of 3 minutes

Figure 6: Detention reservoir at riverbanks. 

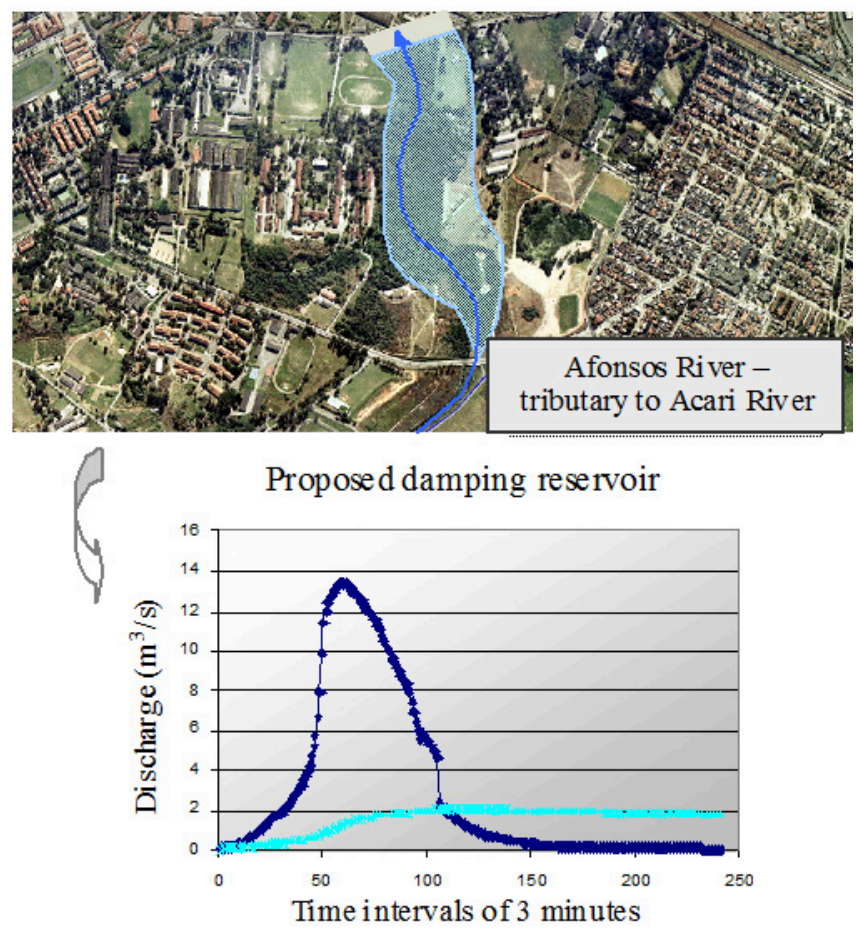

Figure 7: Detention reservoir on Afonsos River - tributary to Acari River.

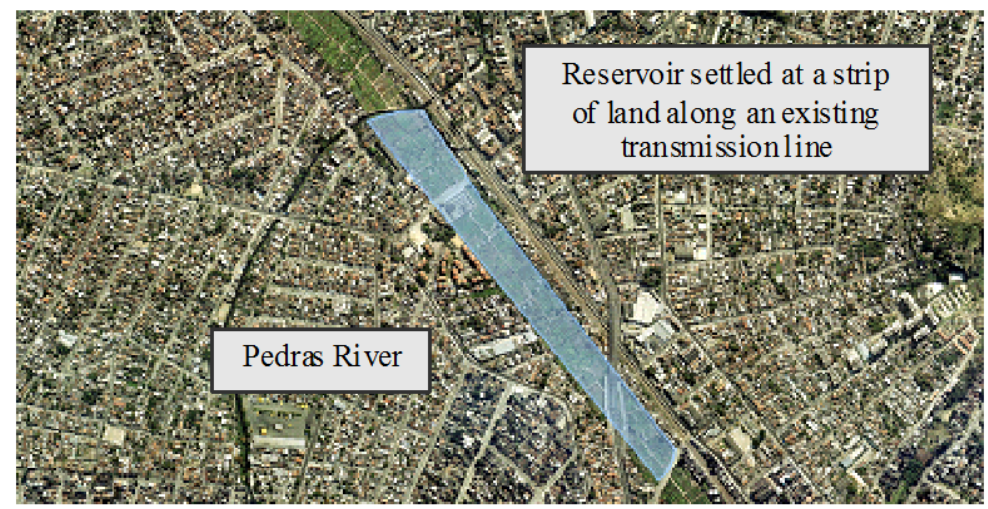

Figure 8: Temporary storage reservoir - water is derived inside reservoir by a lateral broad crested weir set in a tributary of Acari River. After the flood, drainage of the reservoir depends on a pumping station. 


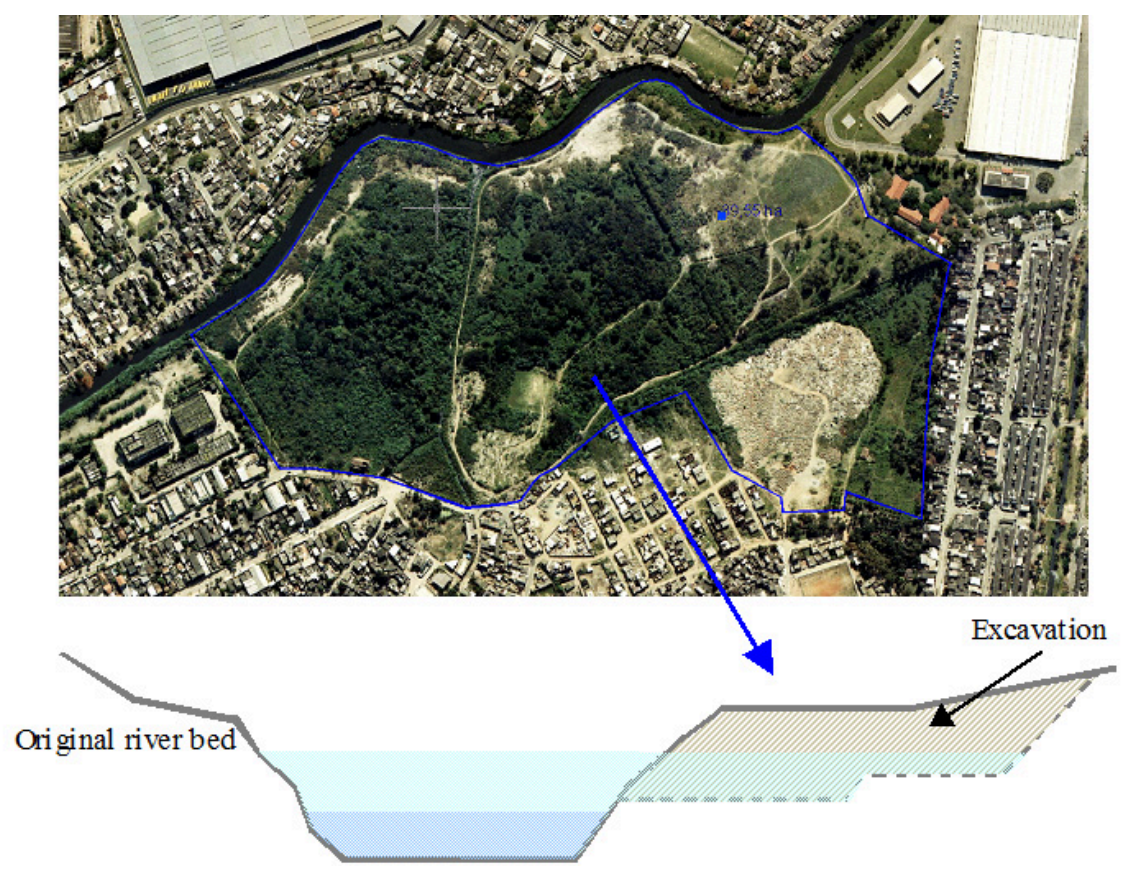

Figure 9: Park implemented in two different levels: the first one prevents that frequent floods access the totality of the park; the second one is to be occupied by design flood.

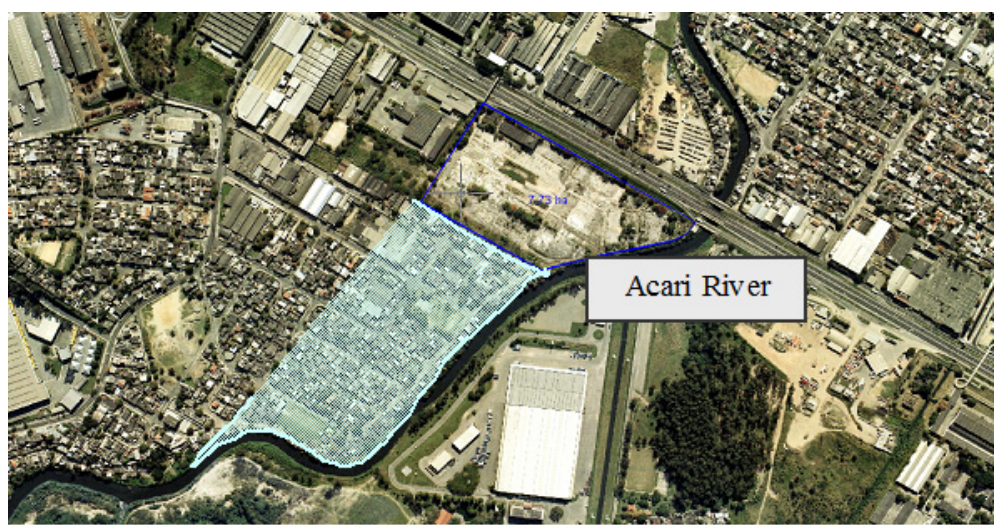

Figure 10: Relocation of part of the community of Parque Columbia, due to a very low level occupation, heavily subjected to floods. 
Table 1: $\quad$ Flood levels comparison.

\begin{tabular}{|c|c|c|c|}
\hline $\begin{array}{l}\text { Control } \\
\text { Point }\end{array}$ & $\begin{array}{c}\text { Localization } \\
\text { (neighbourhood and site) }\end{array}$ & $\begin{array}{c}\text { Flood depths at } \\
\text { present } \\
\text { Situation }(\mathrm{m})\end{array}$ & $\begin{array}{l}\text { Flood depths after } \\
\text { control measures } \\
\text { implementation }(\mathrm{m})\end{array}$ \\
\hline 1 & $\begin{array}{l}\text { Jardim America - } \\
\text { Chambelland Street }\end{array}$ & 0.59 & 0.56 \\
\hline 2 & $\begin{array}{l}\text { Jardim América - Ministro } \\
\text { Arthur Costa Av. }\end{array}$ & 0.27 & 0.27 \\
\hline 3 & $\begin{array}{l}\text { Parque Colúmbia - Leão } \\
\text { Coroado Street }\end{array}$ & 1,70 & 0.77 \\
\hline 4 & $\begin{array}{l}\text { Coelho Neto - Crossing } \\
\text { with Automóvel Clube Av. }\end{array}$ & 1.52 & 0.68 \\
\hline 5 & $\begin{array}{l}\text { Honório Gurgel - Cajatuba } \\
\text { Street }\end{array}$ & 1.16 & 0.61 \\
\hline 6 & $\begin{array}{l}\text { Marechal Hermes - Luís } \\
\text { Coutinho Cavalcanti Street }\end{array}$ & 1.68 & 0.38 \\
\hline
\end{tabular}

The results obtained with the proposed set of interventions were able to reduce significantly floods, but not to solve the entire problem. Flooding is so critical in the present situation that it would be needed a second set of interventions, possibly working on-site, in order to equate problem. Results shown in table 1 , however, need a further explanation to be correctly interpreted. Model simulation assumes a pattern of urbanisation that answers for average characteristics of city occupation. This pattern, defined in the model, considers that buildings floor level is $0.50 \mathrm{~m}$ above street level, as it can be seen in figure 11. This definition implies that traffic is still heavily affected by flooding, but housing is almost free of it, for a 20 years recurrence event.



Figure 11: Urbanisation pattern modelled. 


\section{Concluding remarks}

The solution for Acari River basin floods poses a difficult problem, combining critical flooding levels, social pressures, lack of appropriated infrastructure, and tidal influence. Facing this problem, Rio de Janeiro City Mayor's Office and Federal University of Rio de Janeiro joined efforts in the search of a systemic solution, balancing conveyance and storage approaches. The basin was modelled using MODCEL, in order to predict results from different measure combinations.

After considering the final set of proposed interventions, comparing flood levels at a wide range of control points, there was an average reduction of $30 \%$. However, several critical places had more significant reductions, with results near to $80 \%$ of reduction.

Therefore, flood problems could be reduced, but there would still remain some significantly affected areas. It is important to understand that only a longterm work would produce better results. In order to accomplish a sustainable solution it is required a larger range of actions. Environmental recovery and investment in general urban infrastructure are necessary to revert the situation. Education and social-economic development complete the puzzle to construct the desired solution for the problem.

\section{References}

[1] Rio de Janeiro Mayor's Office. Integrated Rehabilitation of Acari River Basin. Final Report of SMAC "P" Resolution Workgroup, $\mathrm{n}^{\circ}$ 38. Rio de Janeiro, Brazil, 2006. (in Portuguese)

[2] Mascarenhas, F.C.B.; Toda, K.; Miguez, M.G.; Inoue, K. Flood Risk Simulation. WIT Press, Southampton and Boston, 2005.

[3] Zanobetti, D.; Lorgeré, H.; Preissman, A.; Cunge, J.A. Mekong Delta Mathematical Program Construction. Journal of the Waterways and Harbours Division, ASCE, vol.96, n.WW2, pp. 181-199, 1970.

[4] Ahern, J. Greenways as a Planning Strategy. In: Landscape and Urban Planning, vol.33, pp.131-155, Elsevier, 1995.

[5] Seams, R.M. The Evolution of Greenways as an Adaptive Urban Landscape Form. In: Landscape and Urban Planning, vol.33, pp. 65-80, Elsevier, 1995.

[6] Miguez, M.G.; Mascarenhas, F.C.B.; Magalhães, L.P.C. Multifunctional landscapes for urban flood control in developing countries. In: International Journal of Sustainable Development and Planning, vol. 2, Issue 2, 2007. 